\title{
Walter Breu* Actionality and the degree of temporal dynamics
}

\section{Focus aspect, status aspect, and the role of valency}

https://doi.org/10.1515/stuf-2021-1041

\begin{abstract}
The interaction of lexical actionality with grammatical aspect is explained in a comprehensive system, based on the "degree of temporal dynamics" of simple and complex actional classes and of the various functions, expressed by aspect grammemes (extended ILA model, focus aspect). Then a new conceptualization of less frequent aspect phenomena is presented. A novelty is the differentiation of focus aspect from status aspect, characterized by habitualization and the transformation of telic events into atelic activities. Argument structures are claimed to be responsible for class changes, especially with respect to the incorporative (INCO) class, combining activity, telicity and a subsequent state.
\end{abstract}

Keywords: aspect; habituality; process; state; telicity; temporal dynamics; valency

\section{Introduction}

Verbal aspect as the grammatical core of the functional-semantic field of actionality is based on oppositions of aspect grammemes like perfective: imperfective, progressive: simple, imperfect: aorist and the like. The oppositions as such are synchronically invariable, but they interact with aspect-sensitive (actional) features of lexical entries, typically verb lexemes. How the grammatical oppositions are expressed, is language specific, e.g. by means of inflection, as in Romance (restricted to the past), by grammatical derivation with the help of grammatical prefixes, suffixes and suppletion, as in Slavic-style aspect, or analytically by means of particles, as, for example, in Albanian, or in form of periphrases, like the progressive in English and similar gerundial constructions

*Corresponding author: Walter Breu, Department of Linguistics, University of Konstanz, Konstanz, Germany, E-mail: walter.breu@uni-konstanz.de 
in Italian, Albanian etc. A given language can have more than one aspectual opposition, which may also interact among themselves.

This chapter consists of three parts (Sections 2-4). Section 2 gives an overview of the model for the interaction of lexemes with aspect (ILA). The ILA model as a whole is based on the "degree of temporal dynamics" (DTD) as the common feature of both lexical and grammatical actionality. It allows for a unified, typologically relevant description of this interaction and is intended to be a point of reference, $a$ yardstick for comparing/measuring the behavior of aspect categories in different languages, as well as the behavior of actional lexeme classes, or rather for categorizing their individual members, with respect to the aspect category in question. In the extended version of this model, the actional semantics of individual lexemes are claimed to be made up of components with different DTDs, interacting in a characteristic way with the DTD properties of aspect grammemes.

One of the main topics of the present contribution to aspectology is the differentiation of two different types of aspectual manipulations of lexical semantics, often mixed up in existing aspect theories: focusing single actional components (briefly: "focus aspect") and modification of the actional DTD status (briefly: "status aspect").

In Section 3, we will show that this differentiation is essential, for example, in order to understand the double role of the stative aspect function, resulting either in the focus on a state component already present in the given lexical meaning or in transforming an individual event into a secondary (habitual) state. The double role of the processive aspect function (progressive) results either in focusing an ongoing process or in transforming a telic event into an ongoing atelic activity.

The second novelty of this chapter is to integrate the role of valencies in the focusing as well as in the status-modifying operations, especially with respect to non-canonical arguments, which cause typical changes in the actional behavior of verb lexemes. This will be demonstrated in some detail in Section 4 by means of the properties of the complex actional classes, for example the "incorporative" one, combining components of three different DTD classes, i.e. the properties of states, activities and accomplishments in Vendler's (1957) terms. ${ }^{1}$ Our new approach will allow for a more dynamic, context-based handling of lexical DTD features, without

\footnotetext{
1 Due to reasons of space, it is not possible in this chapter to discuss other semantics-oriented aspect models being in some relation with the concepts of the ILA model. This is especially true with respect to typological approaches assigning to the lexical telicity feature an important role for aspectual usage, like Dahl (1981), Krifka (1998), or Tatevosov (2002). For an overview of earlier concepts concerning the connection between aspect and (verb-inherent lexical) meaning see Comrie (1976: 41-51). For a discussion of a wide range of approaches to aspectual behavior, including ILA and many other semantics-based models, see Sasse (2002), Tatevosov (2002: 317-324), and Wiemer (2019).
} 
abandoning the concept of attributing actional characteristics to verbs and not (in Vendler's way) to entire predicates. ${ }^{2}$

In the following, the term "telic", referring to the inherent goal (telos) of a lexical meaning, and the wider notion of "terminative" are used as equivalents. The same is true for "atelic", "aterminative” and the like. This attempt at resolving part of the terminological confusion in aspectology is based on the fact that the goal of a state of affairs coincides with its inherent final boundary (terminus). In the aspectological literature most frequently only one of these corresponding terms is used, with terminative, Russian "predel'nyj”, being preferred in Slavic studies, whereas telic, Russian “celevoj”, is found more rarely. In some works, the two terms refer to different concepts. So, Mehlig (2006: 303-305) differentiates, among other things, between "absolutely terminative" = telic and "relatively terminative" predications, referring to non-terminative "degree achievements", which do not exclude a continuation of the state of affairs in question after the change of situation: For example in temperatura upala $\mathrm{PFv}$ 'the temperature fell', the temperature may continue to fall after having fallen. ${ }^{3}$

\section{The model of the interaction of the lexicon with aspect (ILA)}

First elaborations of a comprehensive concept of the interaction of lexical (actional) semantics and (grammatical) aspect in the given framework go back to Breu (1985) and Sasse (1991a), applied from the very beginning to different languages like Russian, Modern Greek, Cayuga and many others, though the Slavic language family was always in the main focus, as its fairly complicated aspectual system had been studied before for many decades. A step forward may be seen in the algorithmic classification of actional semantics on the basis of four types of boundaries in Breu (1994), ${ }^{4}$ followed by the introduction of complex actional classes; see for example Breu (1998). Since then many authors have based their

2 Vendler's approach of classifying predications instead of verb lexemes, adopted by many authors, has its equivalent in Mehlig's works on aspect in Russian; see, for example, Mehlig (2006). In contrast, the ILA model is clearly based on lexemes, with the context being only secondarily relevant for the actional interpretation of a text; see also Glovinskaja (1982) and Bondarko (1995). 3 See also the discussion of different types of telicity/terminativity in Bondarko (1995: 33-48). In the ILA model all types of inherent boundaries are assigned to terminativity/telicity. The terms "bounded/unbounded", not used in the present paper, are additional synonymic alternatives.

4 The five "degrees of temporal dynamics" in Breu (1994) were deduced directly from these boundary types, in which simple and complex classes were mixed. The INCO class was still missing; see below. 
descriptions of individual aspect systems in languages of the world on elements of the ILA model. ${ }^{5}$ In the last two decades the peculiarities of aspect systems of minority languages in contact have given rise to a further improvement of this model (Breu 2005, 2009, 2012; Breu et al. 2016; Scholze 2008). By now, terminology has become stable, but what has still been missing is a dynamic component, allowing for the interaction of the class behavior of a given verb with the actual filling of its valencies.

\subsection{Basic terms and definitions}

The common basis for the interaction of lexical actionality and grammatical aspect is the "degree of temporal dynamics" (DTD), depending on the probability with which lexical entities and aspect grammemes refer to a change of the state of affairs they express. DTD is essentially based on boundary characteristics of verb meanings and aspect functions (Breu 1994; Sasse 1991a) and by no means restricted to the binary opposition of telic: atelic.

Basically all states of affairs in the real world have a starting point and a final moment, in which they come to their end. Extralinguistic states of affairs have been lexicalized language-specifically in verbs with class-specific boundary characteristics. This is reflected in terms of an initial boundary B1 and a final boundary B2 with the verbal state of affairs (event, action, state) virulent in between. Before B1 there is a sort of prephase, in which the state of affairs is in some way imminent (possibly with preparations), and after B2 there is a postphase in which its effects (consequences, results) are present, being also the background of the new situation in which subsequent states of affairs occur. The conceptualization of the relation between the states of affairs proper and their boundaries forms the aspect-sensitive (actional) part of lexical semantics, which also includes the argument structure (valencies) of the verb. Verbal aspect allows for focusing or modifying the actional properties of verbs within certain limits, typical for the individual actional classes they belong to. Besides this verb-internal interaction, the actional characteristics of the other parts of speech (adverbials, conjunctions etc.), forming the periphery of the field of actionality, contribute to the actional shape of the sentence and the text, too, but they will not be considered in this chapter.

5 See, for example, Sasse (1991b) for Arvanitika, Li (1991) for Chinese, König (1993) for Maa, Leluda-Voß (1997) for the perfect in Modern Greek, Gardenghi (1998) for Italian,Schnell (2011) for Vera'a (North Vanuatu) etc. See also Karolak (2003) for a review of the ILA model and suggestions for its further development. 


\subsection{Actional classes (aspect-sensitive lexicon) and their DTD}

Based on their boundary properties, verbal states of affairs are characterized by their "degree of temporal dynamics" (DTD), corresponding to the probability with which the verbal meaning in question leads to a change of the given situation. The DTDs characterize actional verb classes. These actional DTD classes are the lexical basis for the interaction with grammatical aspect and may also be termed "ILA classes". In Figure 1 the four basic classes are denominated by four-character abbreviations, spelled out on the right and exemplified by a typical member of the given actional verb class, represented by a Russian verb lexeme with its English counterpart as its translation.

It has to be underlined once again that complete Slavic verb paradigms including aspect - in contrast to inflectional systems - are normally formed by means of "grammatical derivation" on the basis of two different stems, each of them having its own partial paradigm for tense, voice, person, number and mood, including the infinitive. This means that a verb lexeme expressing the aspectual opposition, as in the case of ACTI and TTER lexemes in Figure 1, consists of two partner verbs with an identical lexical meaning, differing only in aspect (Glovinskaja 1982: 111). ${ }^{6}$

Such "aspectual pairs" are formally differentiated by (imperfectivizing) suffixes and/or (perfectivizing) prefixes and suppletion. In addition to the examples in Figure 1, see the following cases: dat'/davat' PFV/IPFV 'to give', stroit'/ postroit' ${ }_{\mathrm{IPF}} / \mathrm{PFV}$ 'to build', and klast'/položit' ${ }_{\mathrm{IPFV}} / \mathrm{PFV}$ 'to lay'. More rarely, we have

DTD

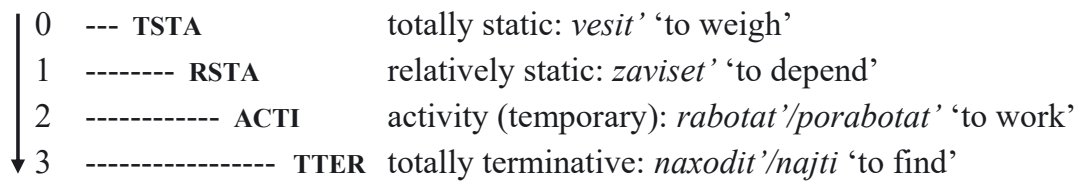

Figure 1: The degrees of temporal dynamics of the simple ILA classes.

6 So, contrary to what Tatevosov $(2002: 362,368)$ presumes, in spite of also accepting the view that it is a pair of verbs in Russian that corresponds to a single verb in languages with inflectional aspect, these two verbs cannot be different lexemes. Due to their lexical identity they must be part of only one lexeme, just like verb forms in inflectional languages. This kind of "grammatical derivation" (Lehmann 2009: 539-544) is clearly different from word formation, conveying a change in lexical meaning. With respect to their functions, aspectual pairs behave exactly like single verbs in inflectional (or periphrastic) systems; see Breu (1984a) for a discussion. As for the complex relation between verb and lexeme in Russian aspectual morphology, see Breu (2009: 210-215). 
suffixes in both partner verbs, for example, in the lexeme obmanut'/obmanyvat' $\mathrm{PFV} / \mathrm{IPFV}$ 'to cheat'.

Note that even prefixes, having their own lexical meaning, do not prevent a pf. prefixed verb from having a lexically identical ipf. partner. This is due to the fact that in combination with the lexical meaning of the ipf. partner verb the lexical meaning of the prefix of its pf. equivalent becomes redundant (doubled, "empty"). In this sense the Russian prefixes po- in stroit'/postroit' IPFV/PFV 'to build', na- in pisat'/napisat' IPFV/PFV 'to write something' and $s$ - in delat'/sdelat' 'to make' becomes purely grammatical, contrary to other prefixes serving as morphemes for word formation, like pod- 'under' in podpisat' 'to sign', forming a lexeme with its ipf. partner podpisyvat'.

In Figure 1 the ipf. verb precedes its pf. correlate. TSTA and RSTA verbs are mono-aspectual imperfectiva tantum, forming lexemes by themselves alone.

TSTA verbs express inalienable states or properties firmly linked to the referent (subject of the verb) without any probability of a change of this situation (DTD 0), while for RSTA verbs a change in time is possible, though not compulsory. In the given example, the referent may depend on something for some time, but also forever (DTD 1), contrary to weigh in the TSTA sense of 'having a weight'.

ACTI verbs behave differently, as the state of affairs they express cannot last for an unlimited time. It is temporary and in this sense it obligatorily leads to a change of situation: no activity can be performed continuously without interruptions (DTD 2). The pf. partner verb in Russian ACTI lexemes, like porabotat' in Figure 1, focuses this temporal B2, thus giving rise to a delimitative reading; see Section 4. While aspectual pairs in the TTER class, like the suppletive lexeme naxodit'/najti 'to find' IPFV/PFV in Figure 1, are generally accepted in Slavic aspectology, this is not true for ACTI pairs like rabotat'/porabotat' IPFV/PFV, whose pf. partners are often treated as delimitative "aktionsart" with an external boundary. See, for example, Bondarko (1995), completely excluding atelic lexical meanings from aspectual pairedness and Mehlig (2006: 35), who nevertheless confirms that aktionsarten are used as obligatory substitutes for missing pf. partners and that they are part of the verbal paradigm of activity predications. On the other hand, Čertkova (1996) argues in favor of the paired character of

7 The lexical redundancy of a prefix added to an ipf. verb in order to get a pf. partner obviously depends on the lexical meaning of both the prefix and the verbal lexeme in question. This explains the variety of grammatical prefixes used in aspectual pairs. Unlike suffix-derived and suppletive pairs, not all authors accept prefix-derived aspectual pairs, see for example Isačenko (1968: 355-365). But most functionally oriented authors do; see Zaliznjak et al. (2015: 91-94) for a discussion. 
delimitative perfectives, as did already Koschmieder (1973) with respect to Polish. ${ }^{8}$

The highest DTD 3 is expressed by verbs of the TTER class, all provided with a boundary that is inherent to the meaning itself, i.e. once the state of affairs has come into existence it is finished as soon as this boundary has been reached. Often such states of affairs are even punctual, i.e. they start and end in the same moment, like in the above example naxodit'/najti 'to find'.

The method of representation used here is to a certain extent simplistic. Verbs do not necessarily have only one meaning, and it is, of course, verbal meanings which are classified here, not verbs. In other words, the various meanings of polysemous verbs are not necessarily characterized by the same degree of temporal dynamics, which means that they possibly belong to different actional classes. ${ }^{9}$ Having this in mind, it is nevertheless possible to use this representation of verb meanings by means of verb forms further on, whenever we refer to the basic or only meaning of the verb in question.

Besides the simple classes in Figure 1, three complex classes may be distinguished, having simple-class characteristics as their components; see Figure 2. DTDs are added here (optionally) as subscripts to the classes. We will do so also in the following, where it seems helpful for the sake of clarity.

The ISTA or "inceptively static" class shows the DTD characteristics 3 and 1 of the basic classes TTER and RSTA, which means that a verb like to understand refers to a change of situation from "not knowing" to "knowing", which at the same time is the beginning of a subsequent alienable state of "knowing" (RSTA).

The GTER or "gradually terminative" class unites the characteristics of the ACTI and the TTER class. The lexemes in this class may refer to an activity leading

8 In the ILA model their delimitative surface meaning is a result of the interaction of the temporarily limited ACTI meaning with pf. aspect. Thus it fulfills the condition for lexical identity of the partner verbs. In other words, it follows from the temporary character of activities that they are always carried out "for a while". The perfective correlates with the po prefix just underline this lexically present feature. In Romance languages with their inflectional aspect such discussions are irrelevant: for example in Italian, the aorist of lavorare 'to work' has the same delimitative function as Russian porabotat'. The same is true for the simple past of to work in English in single events. 9 See the concept of "hybrid predications" in Mehlig (2006: 305-309) and their different actional behavior, depending on different partial meanings, as well as the concept of "categorically conditioned homonymy" in Breu (1984b), responsible for varying partners in aspectual pairs. An example is the case of gotovit' IPFV with the following PFV partners, dependent on the specific meaning in question: prigotovit' 'to prepare (meal)', zagotovit' 'to procure', podgotovit' 'to prepare (materials)' etc. (Lehmann 2009: 538). See also Padučeva (2004: 31-34, 146-176) for many examples of actionally different meanings of single verbs. Her classification of "taxonomic categories" is mainly based on Vendler's classes with the addition of agentivity (agent-controlled, intentional). 


$\begin{array}{ll}\mathrm{ISTA}_{1,3}=\mathrm{TTER}_{3}+\mathrm{RSTA}_{1} & \text { ponjat'/ponimat' 'to understand' PFV/IPFV } \\ \mathrm{GTER}_{2,3}=\mathrm{ACTI}_{2}+\mathrm{TTER}_{3} & \text { rešat'/rešit' 'to resolve' IPFV/PFV } \\ \mathrm{INCO}_{1,2,3}=\mathrm{ACTI}_{2}+\mathrm{TTER}_{3}+\mathrm{RSTA}_{1} & \text { pokryvat'/pokryt' 'to cover' IPFV/PFV }\end{array}$

Figure 2: Complex DTD classes.

to the final boundary B2 or may express their state of affairs as a single whole including its boundaries B1 and B2. Such lexical meanings normally entail a result after B2. A Russian example is the lexeme rešat'/rešit' 'to resolve' with the activity of resolving preceding the final boundary B2.

The INCO or "incorporative" class ${ }^{10}$ is the most complex one. It incorporates the characteristics of the three basic classes ACTI, TTER and TSTA. An example is the Russian lexeme pokryvat'/pokryt' 'to cover', with the perfective pokryt' focusing on the total event, whereas the imperfective pokryvat' may focus on the activity of covering or the resultant state of being covered; see examples (1)-(3) below. ${ }^{11}$

All lexical meanings with a TTER component, i.e. all three complex classes and the single TTER class may be addressed as "telic"/“terminative".

\subsection{Aspectual classes (aspect grammemes) and their DTD}

Aspect grammemes may be classified on the basis of their DTD properties, too, with the Slavic perfective aspect or the Italian/Albanian/Greek/Bulgarian aorist showing degree 3, with obligatory realization of all boundaries (limitative function). On the other hand, the English/Albanian/Italian progressives function as DTD 2 grammemes. The respective counterparts of these marked aspect grammemes express the functions of the remaining degrees, e.g. the Russian imperfective has the DTD properties 0,1, 2, whereas the English simple form has DTD 0, 1, 3; see Figure 3. In line with lexical DTDs, the DTDs of aspect functions are connected with the probability of a change of situation: $0=$ no change in time,

10 In earlier ILA approaches, for example Breu (1998), INCO was the abbreviation of "inchoative", derived from the traditional denomination of an adjective-derived INCO subclass with verbs like zelenet'/pozelenet' IPFv/PFv, German grünen, 'to be/become green', alternatively also termed "mutatives". As the term "inchoative" is often used as a synonym of "inceptive" or "ingressive", it has been replaced now by "incorporative", in order to avoid misunderstandings.

11 There is nothing in Vendler (1957) corresponding to this class, while the GTER class is nearest to Vendler's accomplishments, if we do not consider the fact that he classifies predications, not verb meanings. The ISTA class is also missing, but it was mentioned later on by Johanson (1971), who called it "Initialtransformativa". The simple TTER class is nearest to Vendler's achievements and ACTI to his activities. Among the states, Vendler does not differentiate between TSTA and RSTA. 
1 = change is only optional, 2 = change is obligatory but flexible (like a temporal B2), 3 = change is obligatory (inherent B2 is reached).

Aspect functions are treated here as language-independent, universal, whereas grammemes (grammatical forms) have differing forms and structures in the individual languages or groups.

In contrast to Slavic, where the aspectual opposition is relevant in all tenses and moods, the Romance and Albanian opposition of imperfect versus aorist is restricted to the past indicative. It is expressed by endings and stem oppositions, e.g. Italian ebbi AOR.1SG: avevo IPRF.1SG 'I had' or Albanian pata AOR.1SG: kisha IPRF.1SG 'I had'. In some varieties of Italian the aorist has been replaced by the perfect, now having limitative function.

In Standard Albanian the progressive, formed with the help of the aspectual particle $p o$, is fairly obligatory for the processive function, for example in the present. In the past it is combined with the imperfect, e.g. po punonte 's/he was working'. So the pure imperfect without po is mainly restricted to the expression of stative $_{1}$ and universive $e_{0}$. In Italian there is a specialized progressive, too, but it is not obligatory, though used rather often when a processive should be expressed unambiguously. It is formed periphrastically by means of the auxiliary stare 'to be, to stay' + gerund, e.g. stava lavorando 's/he was working'.

The stative, giving rise to habitual readings, is a function of the ipf. aspect/ imperfect/simple form. There are also specialized habitual periphrases, restricted to the past, like "used to + infinitive" and would + infinitive" in English. They are used for referring unanimously to habitual states of affairs; see below.

There are Slavic varieties like Bulgarian or Molise Slavic (in southern Italy) having both the Slavic opposition of perfectivity and the inflectional opposition of imperfect versus aorist/perfect. These two aspect oppositions may combine freely. As they are parallel with respect to the expression of aspect functions, the combinations of the imperfective imperfect and the perfective aorist are pleonastic. But the contradictory combinations in terms of the perfective imperfect and the imperfective aorist/perfect allow for special effects, like the expression of delimitative states of affairs (imperfective aorist/perfect) and the habitual sequence of events (perfective imperfect); see (Breu 1994, 2014).

\section{ASPECT GRAMMEMES}

\begin{tabular}{|lllcl} 
DTD & ASPECT FUNCTIONS & Russian & Italian/Albanian & English \\
0 --- Universive & IPFV & IPRF & SF \\
1 ------- Stative & IPFV & IPRF & SF \\
2 --------- Processive & IPFV & IPRF (PROG) & PROG \\
3 -------------- Limitative & PFV & AOR (PRF) & SF
\end{tabular}

Figure 3: Aspect grammemes and the temporal dynamics of their functions. 


\subsection{The interaction: focus aspect}

Given this basic system in the lexical and the grammatical domain, aspect may be defined as the "manipulation" of the DTD characteristics of a given lexical meaning by the DTD properties of aspectual grammemes. In other terms, grammatical aspect manipulates the lexical DTD in the direction of the DTD of its own functions, which results in "interaction meanings".

The procedure of superimposing an aspect function on a given lexical meaning can best be understood as an operation with the aspect function as the operator and the lexical meaning as the operandum, resulting in typical ILA meanings. There are two very different operations, which often are not kept apart in aspectology. Most frequently, the term "aspect" is associated with different perspectives of the lexical meaning, which may be understood as focusing (or stressing, not just selecting) an actional component. This is the operation to be termed "focus aspect". The other operation is the complete modification of the actional DTD status. It will be dealt with in Section 3.

Focus aspect has its basic domain in the complex classes. In the simple classes it focuses on the only lexical component present, which leads either to an empty application, for example of the processive ${ }_{2}$ to meanings of the $\mathrm{ACTI}_{2}$ class or of the limitative ${ }_{3}$ to the TTER ${ }_{3}$ class, or it is incompatible, like the processive ${ }_{2}$ with RSTA $_{1}$ states. So, for example, the English progressive operating on an activity like in s/he was working only underlines its prototypical (temporary) actional meaning, but it cannot be used with a (mental) state like 'to know': *s/he was knowing.

In the Russian TTER 3 lexeme prijti/prixodit' $\mathrm{PFv} / \mathrm{IPFV}$ 'to come' pf. aspect with its limitative ${ }_{3}$ function applies emptily, whereas the ipf. aspect is incompatible with this lexeme as far as its processive ${ }_{2}$ function is concerned. Thus, Russian ona prixodila IPFv may never mean a process in the sense of 'she was coming'. In English things are different, as 'to come' is not a TTER verb but rather belongs to the complex GTER class, compatible with the processive (see below). The same GTER affiliation is found even in other Slavic languages, for example, in its Serbo-Croatian equivalent dolaziti/doći IPFV/PFv. In contrast, an ipf. TTER verb like Russian prixodit' expresses only other aspect functions like habituality. This difference is one of many cases showing that superficial equivalence of lexical items of two languages does not automatically entail the same actional properties. It does not impede a language-specific behavior with respect to the grammatical category of aspect, perfectly fitting into the ILA model.

In lexemes of the complex classes, aspect functions emphasize the component with the same DTD, whereas the other components remain in the background. They are not cancelled out completely, however, as for example a $\mathrm{GTER}_{2,3}$ meaning 
like in the transitive lexeme pisat'/napisat' (pis'mo) 'to write (a letter)' remains telic, due to its $\mathrm{TTER}_{3}$ component, which means that even when its $\mathrm{ACTI}_{2}$

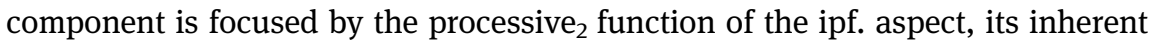
final B2 does not get lost. This is contrary to the atelic meaning of the ipf. intransitively used pisat', which - as a member of the $\mathrm{ACTI}_{2}$ class - only has a temporary boundary. An apparent proof for this is the incompatibility of delimitative popisat', being the partner verb for atelic ipf. pisat', with a referential object like pis'mo, because an inherent B2 contradicts a temporary one. ${ }^{12}$ In contrast, the ipf. activity pisat' reaches its temporary B2 in every single moment of its existence (has been realized, even if it gets interrupted), whereas the telic one may still be referred to as not having reached its inherent boundary B2. Therefore the resultativity test makes sense (does not lead to an ungrammatical sentence): $X$ pisal pis'mo, da ne napisal ego. ' $\mathrm{X}$ was writing a letter, but did not write it (= did not finish it)., 13

The focus operations being at work in the case of GTER meanings like telic pisat'/napisat' 'to write', ubivat'/ubit' 'to kill', vxodit'/vojti 'to enter', ubeždat'/ ubedit' 'to convince' may be represented by the formulas in A and B: A = processive focus of the ipf. aspect, $B=$ limitative focus of the pf. aspect. The focused component is underlined. The operation type is symbolized by a (focusing) point in a circle: $\odot .^{14}$
A. Processive $_{2} \odot \mathrm{GTER} \rightarrow \underline{\mathrm{ACTI}}_{2}+\mathrm{TTER}_{3}$
(ILA $=$ telic process)
B. Limitative $_{3} \odot \mathrm{GTER} \rightarrow \mathrm{ACTI}_{2}+\underline{\mathrm{TTER}}_{3}$
(ILA = telic event, final result)

In ISTA $_{1,3}$ meanings like ponimat'/ponjat' 'to understand', videt'/uvidet' 'to see',

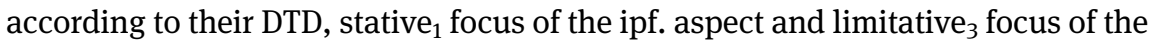
pf. aspect are possible. The characteristic ILA meaning of the limitative ${ }_{3}$ in $\mathrm{C}$ is the beginning of the $\mathrm{RSTA}_{1}$ state of affairs, focused in D.

12 The non-referential character, often underlined by the generic plural (here pis'ma 'letters') applies only for the direct object of the verb itself, but it is not transmitted to anaphoric resumptions. Thus, in the following example, for which I am grateful to an unknown reviewer, pis'mo 'letter' has a non-referential (generic) reading as the object in the first sentence, but becomes referential in the anaphoric pronoun: Posidel, popisal pis'mo. Islil vsju dušu v nego uxx ... (internet) 'He (then) sat (for a while), wrote a letter (for a while). He poured all his soul into it, huh ...'

13 This test, which, in fact, is a GTER test, goes back to Maslov (1948) and is similar to Garey's (1957: 105) telicity test, which can be paraphrased like this: "If somebody was interrupted while $\mathrm{x}$-ing, has $\mathrm{s} /$ he $\mathrm{x}$-ed?" With $\mathrm{x}=$ intransitive pisat' the answer is "yes" ( $\rightarrow$ atelic), with $\mathrm{x}=$ pisat' pis'mo it is "no" ( $\rightarrow$ telic, more exactly GTER).

14 For other formalized aspect operations, including also the interaction of more than one aspect category with the actional classes, see, for example, Breu (2005). 

C. Limitative $_{3} \odot \mathrm{GTER} \rightarrow \mathrm{TTER}_{3}+\mathrm{RSTA}_{2}$
(ILA = beginning of a state)
D. Stative $_{1} \odot$ ISTA $\rightarrow$ TTER $_{3}+\underline{\text { RSTA }}_{1}$
(ILA = state after its beginning)

In the domain of ISTA lexemes we again find many examples proving the assumption that lexemes of different languages corresponding to each other with respect to their general lexical meaning may belong to different actional classes (with different aspectual behavior). For example, Italian avere 'to have' belongs to the ISTA $_{1,3}$ class, with the beginning of the possession being expressed by the limitative function of the aorist, e.g. ebbe 's/he received', whereas the state of having is rendered by the stative function of the imperfect, here aveva 's/he had'. In contrast, English to have and Russian imet' are simple states $\left(\mathrm{RSTA}_{1}\right)$, compatible

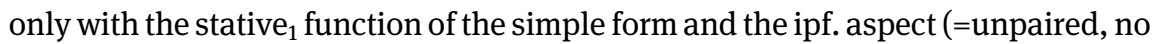
pf. partner verb). Due to language contact with Italian, Molise Slavic jimat has

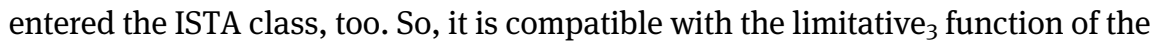
perfect (replacing the aorist), as in je jimala, likewise having the interaction meaning 'she received' (Breu 2005), unlike Russian ona imela 'she had'.

Similarly, Italian conoscere 'to know' is an ISTA verb, too, with the inceptive interaction meaning 'to get acquainted with' in the aorist, unlike English to know and also Russian znat' (in this sense), where the inceptive meaning has to be expressed lexically by poznakomit'sja. The Molise Slavic equivalent poznat'/ poznavat' PFV/IPFV is likewise an ISTA lexeme, but in this case formed by means of grammatical derivation (suffixation).

The most complex INCO $_{1,2,3}$ class, incorporating three components, may be focused by the stative ${ }_{1}$, the processive ${ }_{2}$ and the limitative , $_{3}$ and shows the ILA meanings of both the GTER and the ISTA class:
E. Processive $_{2} \odot \mathrm{INCO} \rightarrow{\underline{\mathrm{ACTI}_{2}}}_{2}+\mathrm{TTER}_{3}+\mathrm{RSTA}_{1}$ (ILA = telic process)
F. Stative $e_{1} \odot \mathrm{INCO} \rightarrow \mathrm{ACTI}_{2}+\mathrm{TTER}_{3}+\underline{\mathrm{RSTA}}_{1}(\mathrm{ILA}=$ state after its beginning)
G. Limitative $_{3} \odot \mathrm{INCO} \rightarrow \mathrm{ACTI}_{2}+\underline{\mathrm{TTER}}_{3}+\mathrm{RSTA}_{1}$ (ILA = telic event, final result and beginning of a state)

The confrontation of three aspectual operations in (1)-(3) shows that Russian pokryvat'/pokryt' is an $\mathrm{INCO}_{1,2,3}$ lexeme, and so is its English counterpart to cover or, for example, Italian coprire with the opposition copriva IPRF.3sG: coprì AOR.3sG.
(1) Snega pokryvali IPFV polja.
E. Focus $\mathrm{ACTI}_{2}$ (telic process)
'Masses of snow were covering the fields (more and more).'

(2) Snega pokryvali IPFV polja. F. Focus $\underline{\mathrm{RSTA}_{1}}$ (state = polja byli pokryty)

'Masses of snow covered the fields.' (= the fields were covered) 
(3) Snega pokryli PFV polja. G. Focus TTER $_{3}$ (ILA: total event/beginning of a state) 'Masses of snow covered the fields.'

In Russian and Italian, due to the distribution of their aspect functions, the formulas $\mathrm{E}$ and $\mathrm{F}$ ( stative $_{1}$ and processive $\mathrm{f}_{2}$ ) require the ambiguous imperfect(ive). The English mono-functional progressive is restricted to E, the Russian pf. aspect to G. The English simple form is ambiguous for F and G. For more INCO examples see Section 4.

The differences between all four (terminative/telic) classes, including the simple TTER class, may be illustrated by the temporal relations they have with respect to a point in time fixed by an event in the limitative 3 . This is made clear by the so-called "ten-o'clock test" in Figure 4 (Breu et al. 2016: 84). In order to test the class affiliation, it is crucial to see how the situations expressed by the imperfective aspect (process, state) relate to the point of time fixed by the limitative (pf. aspect). For example, a given lexeme like rešat'/rešit' 'to solve' is a member of the GTER class, because the ipf. process rešala 'was solving' refers to the time BEFORE 10 o'clock, fixed as B2 by pf. ona rešila zadaču v 10 časov 'she solved the problem at 10 o'clock'. In contrast, in the case of ISTA lexemes like ponimat'/ponjat' 'to understand' it is the other way round: the ipf. state ponimala 'understood' refers to the time AFTER 10 o'clock, fixed as B2 by pf. ona ponjala problemu v 10 časov 'she understood the problem at 10 o'clock'; due to the double function of the English simple form as a stative ${ }_{1}$ and a limitative ${ }_{3}$, understood is ambiguous here (state, event). As for INCO lexemes like pokryvat'/pokryt' 'to cover' in examples (1)-(3) above, pokryvat' as a process 'was covering' (1) refers to the time BEFORE 10 o'clock, but as a state 'is covered' (2) it refers to the time AFTER 10 o'clock, fixed as B2 by pf. pokryl 'covered' (3). Finally, ipf. TTER verbs like naxodit' 'to find' can refer neither to the time before nor after the boundary fixed by the pf. verb in an example like ona našla grib v 10 časov 'she found the mushroom at 10 o'clock', as they are incompatible both with the processive and the stative.

\begin{tabular}{|c|c|c|c|}
\hline Limitative $_{1}=$ at $10 o^{\prime}$ clock & before 10 & after 10 & Lexeme IPFV/PFV \\
\hline GTER $_{2,3}$ & + & - & rešat'/rešit' \\
\hline ISTA $_{1,3}$ & - & + & ponimat'/ponjat' \\
\hline $\mathrm{INCO}_{1,2,3}$ & + & + & pokryvat'/pokryt' \\
\hline TTER $_{1}$ & - & - & naxodit'/najti \\
\hline Aspect functions (focus) $\rightarrow$ & Processive $_{2}$ & Stative $_{1}$ & \\
\hline
\end{tabular}

Figure 4: The "ten-o'clock test" for the DTD classification of telic verbs. 


\section{Modification: status aspect}

Though often mixed up with focus aspect, status aspect is quite different from it. While focus operations just emphasize the lexical DTD counterpart of the actional meanings and leave their DTD structure intact, status aspect replaces it by its own DTD. The most commonly known status operation is stativization, i.e. the substitution of a higher DTD by the DTD of the stative ${ }_{1}$. This is essentially important for lexical meanings with a $\mathrm{TTER}_{3}$ component becoming in this way "secondary states." ${ }^{15}$ But other DTDs can be affected by this aspectual operation, too, for example $\mathrm{ACTI}_{2}$, and even states may be transformed into habitual states. In principle, stative status may be expressed just like stative focus, i.e. by the ipf. aspect in Slavic or the imperfect in Romance or the simple form in English. Thus, for example in Russian, the ipf. aspect is compatible in its status-modifying stative ${ }_{2}$ function with $\mathrm{TTER}_{3}$ meanings, unlike stative ${ }_{1}$ focus. An example is the aforementioned lexeme prixodit'/prijti 'to come', where ona prixodila IPFV.PRS.3sG means 'she came (usually)'. But often more or less grammaticalized special forms for expressing habituality like those with used to and would in the English past tense have developed. ${ }^{16}$

In order to give examples from a lesser used language, we have quoted in (4) two examples from Burgenland Croatian, a Slavic minority language in Austria. Here the habitual is formed by means of the auxiliary tit 'will, to want' + infinitive. ${ }^{17}$ It is very frequent and combines with all simple and complex classes above DTD 0 . Example (4b) shows that even RSTA ${ }_{1}$ states may be expressed as repeated.

\begin{tabular}{|c|c|c|c|c|c|c|}
\hline a. & $\begin{array}{l}\text { Zimi } \\
\text { winter.LOC } \\
\text { žien. } \\
\text { woman.GEN. } \\
\text { 'In winter } \mathrm{m}\end{array}$ & $\begin{array}{l}\text { je } \\
\text { AUX.PRS.3SG }\end{array}$ & $\begin{array}{l}\text { tilo } \\
\text { will.PTCP.SG.N }\end{array}$ & $\begin{array}{l}\text { duojt } \\
\text { come.PFv. }\end{array}$ & & $\begin{array}{l}\check{c ̌ u d a} \\
\text { much }\end{array}$ \\
\hline b. & $\begin{array}{ll}\text { To } & \text { je } \\
\text { this } & \text { AUX. }\end{array}$ & $\begin{array}{c}\text { tilo } \\
\text { will. }\end{array}$ & $\begin{array}{ll} & \text { jako } \\
\text { G.N } & \text { very }\end{array}$ & $\begin{array}{l}\text { lipo } \\
\text { beautiful }\end{array}$ & $\begin{array}{l}\text { bit. } \\
\text { be.IP }\end{array}$ & FV. INF \\
\hline
\end{tabular}

15 The term "secondary state" was used for habitual events already by Vendler (1957).

16 For a general overview of how habituality has been investigated as a grammatical category see Boneh and Jędrzejowski (2019).

17 Note the typological similarity with the English habitual construction with would + infinitive, without any mutual influence of these two languages. In the southern varieties of Burgenland Croatian the auxiliary tit is replaced by moć 'can' (Breu et al. 2016: 109). 
The formula for stative-status operations in (4) runs as presented in $\mathrm{H}$, irrespective of the DTD of the lexeme, here GTER. The symbol " $\times$ ” means that the lexical DTD is cancelled, or rather replaced by the DTD of the status-modifying stative ${ }_{1}$ function.

\section{H. Stative $_{1} \times \mathrm{GTER}_{\rightarrow} \rightarrow \mathrm{RSTA}_{1} \quad$ ILA: habitual event (secondary state)}

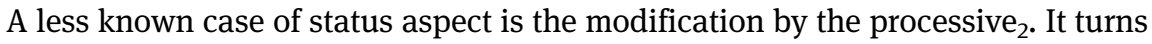
the actional behavior of other DTD classes into that of $\mathrm{ACTI}_{2}$ lexemes. For lexemes with a TTER 3 component this means that they become atelic processes. We may call this operation "actual aterminativization".

There are two possible methods of transforming a telic lexeme into an atelic ongoing activity. The first one is by converting the inherent boundary B2 into a temporary one. For example, in the abovementioned GTER lexeme pisat'/napisat' pis'mo IPFV/PFV 'to write (a letter)' B2 is determined by the properties of the concrete, referential object pis'mo. In the processive ${ }_{2}$ focus operation the telic process continues until the letter has been written as the inherent boundary B2 of this state of affairs. But if the object instead of referring to an individual letter just indicates its type, often expressed by a generic plural, it loses its characteristics as a B2; it even becomes optional. This is exactly the ILA meaning of the processive status operation. In such an atelic usage of 'to write' a limitative ${ }_{3}$, operating on an inherent final boundary is contradictory. So, there is no pf. partner of this type for the atelic, optionally transitive pisat', but only popisat' with its delimitative interaction meaning.

The second way of making telic states of affairs atelic by means of the status-modifying processive is the unlimited continuous iteration of single punctual states of affairs, which in Russian are normally expressed by semelfactives of the type stuknut'/stučat' PFV/IPFV 'to knock'. In this subgroup of the simple $\mathrm{TTER}_{3}$ class the processive ${ }_{2}$ function of the ipf. verb cannot operate as a focus aspect at all, but only as a status aspect, transforming the single punctual state of affairs into a continuum of currently repeated entities. The resulting ILA meaning is once again a secondary atelic activity with a temporal boundary. The formula for the processive $_{2}$ status operation in I refers to all ILA classes with a TTER component, whose lexical DTD it replaces. What is true for Russian pisat'/napisat' and stučat'/stuknut' is valid for their English counterparts to write and to knock as well.

I. processive $_{2} \times \mathrm{TTER} \rightarrow \mathrm{ACTI}_{3}$ ILA: atelic process

While the processive status-modifying operation is normally less frequent or at least less salient than processive focus among the functions of the ipf. aspect in Slavic or other $\mathrm{DTD}_{2}$ aspects like the English progressive, this is different in 
Colloquial Upper Sorbian. In this variety in total language contact with German, focus operations have been lost completely, but the aspect category has nevertheless been preserved, restricted to status operations. This means that in this micro-variety, in contrast to all the other Slavic languages, stative ${ }_{1}$ status and processive $_{2}$ status operations are the only functions of what formally is the "imperfective" correlative verb. In contrast, the use of traditionally "perfective" forms becomes obligatory for lexemes with a TTER component, or in other words, it is even used for telic processes.

As a consequence of this tight relation of pf. aspect and telicity, the aspect category of this language has developed into a grammatical opposition of \pm telicity. As a matter of fact, it is expressed by the traditional Slavic forms of pf. and ipf. aspect, with the latter used for atelic verbs, but also for basically telic lexemes affected by status aspect (habitualization, actual aterminativization). Contrary to other languages, in which telicity is a lexical property of verbal meanings, it is grammatical in Colloquial Upper Sorbian, with telic and atelic realizations of actional meanings with a TTER component, following the rules of state-modifying aspect operations.

Due to its specialized system, restricted to status aspect, Colloquial Upper Sorbian offers formally expressed differences between telic and atelic readings "normal" aspect languages do not have, for example, the opposition between atelic and telic processes by means of the ipf. (5a) versus the pf. aspect (5b). As we can see from the two possible translations of (5a), the "imperfective" form is ambiguous for atelic single events (processive ${ }_{2}$ status) and for habitual statements (stative status $)^{18}$
a. Jan
stwi
šetožwe
liste.
Jan room.LOC
translate.IPFV.PRS.3sG
letter.ACC.PL
'J. is translating letters in his room.' = 'J. translates letters in his room.'
b. Jan rune jen list šetoži.
J. just INDF letter translate.PFV.PRs.3sG
'Jan is just translating a letter (in order to finish it).'

Processive status in (5a) is characterized by the generic plural of the object (which could be omitted altogether), whereas the object in (5b) is a referential argument, as required by the undergoer valency of the verb šełožwać/šełožić 'to translate'.

18 See Breu (2005, 2012) and Scholze (2008) for more examples and Breu et al. (2016) for a comparison with other Slavic minority languages, provided with a normal Slavic opposition of perfectivity: Molise Slavic and Burgenland Croatian. 


\section{The role of valencies in complex DTD classes}

The actional (aspect-sensitive) behavior of lexemes may change due to the characteristics of their valency structure and the arguments actually present. ${ }^{19}$ This section will deal with this influence of valencies and their arguments on the affiliation of lexemes to different DTD classes in Russian. We will especially examine some peculiarities of the most complex DTD class - INCO $_{1,2,3}$ (incorporative) - only very rarely dealt with in aspect theories. ${ }^{20}$ Among other things, there are valency restrictions for INCO lexemes, for example due to their activity $_{2}$ component, requiring agent control.

The Russian lexeme ob"jasnjat'/ob"jasnit' IPFV/PFv 'to explain, make clear' may serve as an example. As (6a) shows, this aspectual pair is basically affiliated to the GTER $_{2,3}$ class, allowing for a juxtaposition of a telic process, due to focusing

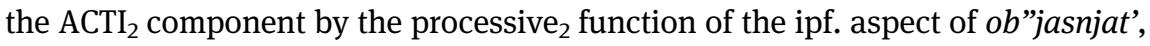
and the limitative ${ }_{3}$ function of the pf. aspect of ob"jasnit', focusing the $\mathrm{TTER}_{3}$ component of its complex DTD; see Maslov's (1948) test, mentioned in Section 2.4. As in (6a), a slightly adapted example from the classic literature, corresponding to this test, the ipf. verb expresses the lexical meaning as a process after its left boundary B1 (beginning), the only boundary to be negated by the pf. verb is its inherent B2, serving also as the final boundary of the telic process, expressed by the ipf. verb.

$$
\begin{array}{llllll}
\text { a. Ob"jasnjal } & \text { ja } & \text { eto, } & d a & \text { ne } & \text { ob”jasnil. } \\
\text { explain.IPFV.PST.SG.M } & \text { I } & \text { this } & \text { but } & \text { NEG } & \text { explain.PFV.PST.SG.M }
\end{array}
$$

'I tried to explain, but didn't explain (successfully).'

[Source: M. Gor'kij, Zykovy, adapted]

The subject of the sentence, ja 'I', functioning as an agent argument of the two verbs, started to explain but did not succeed (did not reach B2), which results in a secondary conative ILA meaning. Sentence (6a) is elliptic as the lexeme

19 For a general overview of the effects of deviations from prototypical arguments (actants) in Russian transitive verbs, see Anstatt (1996) and, with a special reference to metaphor and metonymy related to non-canonical (nesobstvennye) arguments, Breu (1998: 76-78) and Padučeva (2004: 72-79, 416-424). In principle, the influence of arguments and other contexts on actional semantics had already been shown by Vendler (1957).

20 Rare exceptions in aspectual research paying at least some attention to the complexity of the INCO class are Glovinskaja (1982) and Padučeva (2015). In Tatevosov (2016: 232-244) the INCO class corresponds to "stativno-processnye glagoly"; see the discussion in Wiemer (2019: 121). For some reflections on the context-influenced behavior of INCO (and other complex classes) in the ILA framework see Breu (1998). Persohn (this volume), addressing the members of the INCO class as "two-phase verbs", compares their usage and distribution in three different aspectual settings. 
ob"jasnjat'/ob"jasnit' has an experiencer valency, whose argument is missing, without any consequence for the actional meaning. As a matter of fact, it could easily be inferred from the wider context or made explicit by adding emu 'him' in the first part of the complex sentence. Of course, the undergoer argument (object) eto could also be put in concrete terms, e.g. as 'the problem'. So (6a) could be made more explicit as Ob"jasnjal ja emu problemu (ACC.SG.F), da ne ob"jasnil. After B2 the pf. verb ob"jasnit' would normally entail a postphase result in the sense of "the problem was clear to him", which, in fact, did not happen here, as the final boundary due to the negation of the limitative component was not reached.

Obviously, the agent valency of the lexeme ob"jasnjat'/ob"jasnit' is filled in the ordinary way by the subject ja 'I' in (6a). In contrast, the inanimate argument predpoloženie 'supposition' in (6b) does not fill this valency properly.

\section{b. Takoe such} ob"jasnjalo explain.IPFV.PST.SG.N $\begin{array}{lll}\begin{array}{l}\text { predpoloženie } \\ \text { supposition }\end{array} & \text { xot’ } & \text { kak-to } \\ \text { at.least } & \text { somehow } \\ \text { behavior.ACC.SG } & \text { brata. } & \text { brother.GEN.SG }\end{array}$

'Such a supposition at least in some way explained the behavior of his brother.'

[Source: K. N. Dmitrievna, Kod fortuny]

As a consequence of this non-canonical (unsatisfactory) argument for the agentive valency of the basic lexical meaning of ob"jasnjat'/ob"jasnit', this lexeme changes its class behavior. More precisely, what happens here is the deletion of the $\mathrm{ACTI}_{2}$ component as it depends on an agent. As a result, the complex GTER $_{2,3}$ affiliation seems to change into an $\mathrm{RSTA}_{1}$ reading focused by the stative $\mathrm{f}_{1}$ function of the imperfective aspect in (6b). Perfective aspect (limitative ${ }_{3}$ focus), systematically excluded in the RSTA $_{1}$ class is, however, possible in such situations with an inanimate argument filling the agent valency, too; see (6c). ${ }^{21}$

$\begin{array}{llll}\text { c. Etto ob"jasnilo } & \text { mgnovennuju } & \text { peremenu } \\ \text { this } & \text { explain.PFV.PST.SG.N } & \text { sudden.ACC.SG.F } & \text { change.ACC.SG } \\ v & \text { ego } & \text { otnošenii. } & \\ \text { in his } & \text { behavior.LOC.SG.N } & \\ \text { 'This explained the sudden change in his behavior.' }\end{array}$

[Source: litmir, Ėjri]

Again there is an $\mathrm{RSTA}_{1}$ reading present, namely that the "reason for the sudden change in his relations was clear", which could be addressed directly by means of

21 A similar example from the internet is: Posle že ego smerti predskazanie ob"jasnilos' samo soboj. 'But after his death, the prophecy became clear by itself.' 
the ipf. partner verb, here ob"jasnjalo (explain.IPFV.PST.SG.N). But it is presented as following automatically from the event reaching its final boundary B2 immediately after its beginning $\mathrm{B} 1$, which results from the limitative ${ }_{3}$ expressed by the pf. aspect in (6c). This means that the unusual argument constellation represented in (6b) and $(6 \mathrm{c})$, in contrast with the ordinary agentive argument in (6a), allows only for focusing an $\mathrm{RSTA}_{1}$ component by means of the ipf. aspect and a TTER 3 component by means of the pf. aspect of the lexeme ob"jasnit'/ob"jasnjat'. In other words this GTER $_{2,3}$ lexeme behaves in the given case like a member of the ISTA ${ }_{1,3}$ class.

Let us now have a look at the agentive $\mathrm{INCO}_{1,2,3}$ lexeme prjatat'sja/sprjatat'sja 'to hide (oneself)'. In (7a) the subject gnomik 'gnome' is an agent, filling the agentive valency of this lexeme and allowing for the prototypical results of the lexical-aspectual interaction. The pf. partner sprjatat'sja in (7a), due to its limitative function focusing its $\mathrm{TTER}_{3}$ component, has the ILA reading of the total event of hiding, including B1 and B2 and entailing the $\mathrm{RSTA}_{1}$ state of "being hidden".

a. Gnomik mgnovenno sprjatalsja
$\begin{aligned} & \text { gnome suddenly hide.PFV.SG.M.REFL } \\ & \text { 'The gnome suddenly hid behind a tree.' }\end{aligned}$

[Source: litmir, Tuškan]

As expected, the ipf. partner prjatatsja in (7b) has two readings, as the ipf. grammeme has two aspect functions relevant here, processive ${ }_{2}$ and stative ${ }_{1}$. The first reading follows from the processive ${ }_{2}$, focusing the $\mathrm{ACTI}_{2}$ component of the INCO $_{1,2,3}$ lexeme, with the ILA meaning of "the gnome running towards the hiding place behind the tree" (telic process). As the processive is formally expressed in English by the progressive, it is obvious that this grammeme is to appear in the English translation of the Russian sentence.

\begin{tabular}{|c|c|c|}
\hline $\begin{array}{l}\text { b. Gnomik } \\
\text { gnome }\end{array}$ & $\begin{array}{l}\text { prjatalsja } \\
\text { hide.IPFV.SG.M.REFL }\end{array}$ & $\begin{array}{l}z a \\
\text { behind }\end{array}$ \\
\hline
\end{tabular}

'The gnome was hiding (=was running to hide) behind a tree.'

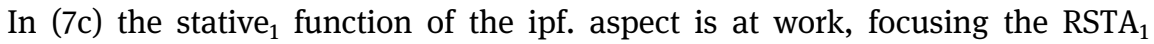
component of the $\mathrm{INCO}_{1,2,3}$ lexeme. While the movement of hiding (into the hiding place) in (7b) regularly requires the accusative for the hiding place, the instrumental is typical for the stative reading in (7c).

$$
\begin{aligned}
& \text { c. Gnomik prjatalsja } \quad z a \quad \text { derevom. } \\
& \text { gnome hide.IPFV.SG.M.REFL behind tree.INS } \\
& \text { 'The gnome was hiding behind a tree.' }
\end{aligned}
$$


Examples like (7a), containing the pf. aspect, always express motion. So, only the Acc should be possible here. However, a brief look into the Russian National Corpus shows that the instrumental is used, too. Literally, this could mean that the 'gnome' hid somewhere behind the tree. But often speakers do not see this difference, so both cases are used more or less synonymously. As a matter of fact, this is possible in ipf. processes like (7b), too, with the same widened concept of the hiding place, but never the other way round, i.e. with an accusative instead of the instrumental in (7c).22

The English progressive appears in the translation in spite of the stative ${ }_{1}$ reading, as the state of affairs expressed here is clearly temporary. This is a general phenomenon in INCO lexemes if the undergoer argument (expressed by the reflexive postfix -sja in Russian and not expressed at all in English) is referentially identical with the agentive argument. It has the characteristics of a potential agent, able to stop the state in which $\mathrm{s} / \mathrm{he}$ is, which therefore is conceived as agentcontrolled.

Once again the behavior of canonical $\mathrm{INCO}_{1,2,3}$ lexemes changes, whenever the agent valency is not filled by an agent, but rather by an inanimate substitute as in (8), where only the stative ${ }_{1}$ reading, focusing the $\mathrm{RSTA}_{1}$ component is possible. The processive ${ }_{2}$ reading is excluded, precisely because the $\mathrm{ACTI}_{2}$ component of the $\mathrm{INCO}_{1,2,3}$ lexeme is deleted.

$\begin{array}{llll}\begin{array}{l}\text { Kamen' } \quad \text { prjatalsja } \\ \text { stone }\end{array} \text { hide.IPFV.PST.SG.M.REFL } & z a & \text { behind } & \begin{array}{l}\text { derevom. } \\ \text { tree.INS.SG }\end{array} \\ \text { 'The stone hid behind a tree.' } & & \end{array}$

But in contrast to the case of ob"jasnjat'/ob"jasnit' 'to explain' in (6), even the $\mathrm{TTER}_{3}$ component seems to be deleted, as the pf. aspect is not possible either, as long as the 'stone' is seen as an immobile undergoer. But it could appear again, if the 'stone' is presented metaphorically as something in motion, perhaps because it is rolling down a hill. In this case a pf. form sprjatalsja would be possible in (8), with its limitative function focusing $\mathrm{TTER}_{3}$. The $\mathrm{INCO}_{1,2,3}$ lexeme would, indeed, show the behavior of an ISTA $_{1,3}$ class member with the pf. form expressing the

\footnotetext{
22 A similar situation exists in German, too, independent of aspect, missing as a grammatical category in this language. An event corresponding to (7a) or a process like in (7b) should have the accusative, expressing motion, here: Der Gnom versteckte sich hinter den (ACC) Baum. But, nevertheless, many speakers prefer the dative, normally expressing the local position in German, not only in a situation corresponding to (7c): Der Gnom versteckte sich hinter dem (DAT) Baum. In English there is no such alternation for the preposition behind, but we find it when a motion 'into' is expressed, which again is often replaced by local 'in', basically expressing the stative localization; see, for example, the variation in The gnome hid in(to) the woods.
} 
beginning of the RSTA ${ }_{1}$ state of affairs, expressed by its ipf. partner. Otherwise the INCO $_{1,2,3}$ lexeme prjatat'sja/sprjatat'sja is reduced to RSTA 1 behavior alone.

Other INCO lexemes behave in a slightly different way. See again the examples (1)-(3) above with the lexeme pokryvat'/pokryt' 'to cover', with the agentive valency filled by the argument snega 'masses of snow'. It is clearly inanimate, but it has a temporary property when falling, to which in the $\mathrm{ACTI}_{2}$ component of the lexeme can refer. Therefore, here all three prototypical ILA meanings are possible, in spite of the argument 'snow' not being a normal agent. On the other hand, it loses its agent-like properties, as soon as it is in its static position, i.e. when RSTA is focused by the stative function of the ipf. aspect in (3). The same would be true for the 'stone' in a falling movement in example (8). ${ }^{23}$

A further case of an $\mathrm{INCO}_{1,2,3}$ lexeme behaving like a member of the ISTA class in case of a non-canonical argument filling its agentive valency is ostanovit'sja/ostanavlivat'sja 'to stop (oneself)'. With a canonical agent in subject position this lexeme clearly presents its $\mathrm{ACTI}_{2}$ component, focusable by means of the processive ${ }_{2}$ function of the ipf. aspect. This is true even in the case of a subject implicitly referring to an agent, who makes it carry out the action in question, like poezd 'train' in (9a), metaphorically filling the agent valency. As a consequence of the processive reading of the first verb, the whole sentence (9a) expresses the taxis constellation of an Inzidenzschema, i.e. a case of backgrounding with an intervening event, in this case expressed by the pf. počustvovali 'felt' in the second clause $\left(\mathrm{ISTA}_{1,3}\right.$ lexeme čuvstvovat'/počustvovat' 'to feel' IPFV/PFv).

a. Kogda poezd ostanavlivalsja, ljudi počustvovali tolčok.
when train stop.IPFV.PST.3SG people feel.PFV.PST.SG jerk
'When the train was stopping (=was coming to a stop), the
people felt a jerk.'

[Source: Večernij Grodno 25.08.2010].

Of course, the other focus operations possible for $\mathrm{INCO}_{1,2,3}$ lexemes would be possible here, too. Due to the $\mathrm{RSTA}_{2}$ focus, managed by the stative function of the ipf. aspect, example (9a) may also have a reading referring to the time after the train had stopped in the sense of: 'When the train was in a halt, people felt a jerk'. Replacing ipf. ostanavlivalsja in (9a) with the pf. form ostanovilsja would result in

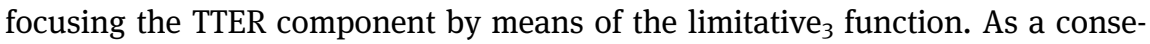
quence the process of 'stopping' would turn into a total event, preceding the

23 This assertion is confirmed by the fact that the English progressive - in contrast to the case with a normal agent - is excluded in both cases. Only the simple past hid, covered would be possible in the given examples, except for situations in which the state is explicitly marked as temporary for other reasons. 
second event počustvovali in this sentence. Both clauses would thus express the taxis constellation of a chain of subsequent total events, each of them with its own resultant state, with the train not moving and people feeling (experiencing) the consequences of the jerk.

Apart from such metaphoric pseudo-agents like 'train', inanimate subjects cannot fill the agentive valency of this lexeme properly, which again means that ipf. aspect only focuses the RSTA 1 component, like the state in (9b). ${ }^{24}$

b. Rasskaz ostanavlivalsja zadolgo do končiny geroja.
story stop.IPFV.PST.3SG long before death.GEN.SG hero
'The story stopped (= had come to a stop) long before the hero's
death.'

The corresponding pf. verb with its limitative function focuses the TTER component, resulting in a total event, which at the same time is the beginning of the RSTA state. Thus replacing the ipf. ostanavlivalsja in (9b) by the pf. ostanovilsja would mean that the story stopped here and then stayed stopped. ${ }^{25}$

Not only the non-canonical filling of an agentive valency may have an influence on the actional behavior of verbal lexemes, but also the undergoer (object) argument of transitive verbs. The already discussed GTER $_{2,3}$ lexeme pisat'/napisat' 'to write' and also čitat'/pročitat' 'to read' and their interaction with the statusmodifying processive are clear examples in this respect. They have an undergoer valency normally filled by a referential quantitatively determined argument like pis'mo 'letter'. It is responsible for individuating an inherent boundary B2 to be reached, in order to realize the state of affairs in question in its totality, thus being a prerequisite for the presence of the $\mathrm{TTER}_{3}$ component. As a consequence, filling

24 This example is a slightly abridged variant with geroja instead of the original znamenitogo pisatelja GEN.SG 'of the famous writer' (https://www.centrmag.ru/catalog/product/posmertnye zapiski/). For some native speakers of Russian ostanavlivalsja IPFv sounds strange, i.e. they would prefer ostanovilsja PFv. In addition, they do not accept an RSTA interpretation of (9a), which means that the aspectual pair ostanavlivat'sja/ostanovit'sja 'to stop' is for them just a GTER lexeme with the components ACTI + TTER, as was also claimed in Breu (1998: 74, fn. 20), in contrast to its German "equivalent" halten (INCO). But the existence of examples like (9b) clearly shows that there are, indeed, texts, in which this pair is treated as an INCO lexeme. As it seems, examples like the following speak in favor of an INCO lexeme with a static (RSTA) reading, too: Pri etom orator dolgo ostanavlivalsja IPFv na generale. 'Here the orator stopped for a long time at the general'.

25 Note that this is an alienable, possibly temporary state $\left(\mathrm{RSTA}_{1}\right)$, i.e. the story may continue in the direction of the hero's death after an interruption by a subplot. If (9b) is supposed to char-

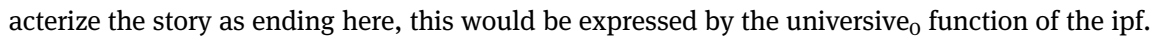
aspect, being never possible in terms of focus aspect but only as a modification in terms of the status-modifying type, transforming in this case the $\mathrm{INCO}_{1,2,3}$ lexeme into a secondary $\mathrm{TSTA}_{0}$ (totally static) lexeme. 
this valency with an inappropriate argument or not filling it all means that the $\mathrm{TTER}_{3}$ component is deleted, thus making the $\mathrm{GTER}_{2,3}$ lexemes behave like atelic $\mathrm{ACTI}_{1}$ lexemes.

An unlimited plural pis'ma 'letters' or pis'mo in a non-referential sense are such non-canonical arguments, which in the end make the lexemes in question behave as if there wasn't any argument at all, but only a kind of incorporated specification, giving the state of affairs a less general meaning, in the sense of, so to speak, "to letter-write", to "letter-read". In such cases of the reduction of $\mathrm{GTER}_{2,3}$ lexemes to $\mathrm{ACTI}_{2}$ behavior there is no bases for focusing a TTER 3 component, which means that the pf. aspect is excluded. As a consequence such readings with a non-canonical undergoer are incompatible with their perfective partners napisat' and pročitat', obligatorily requiring a referential undergoer (object). In other words, pisat' and čitat' without a referential undergoer become imperfectiva tantum in the domain of focus aspect.

They do, however, allow for status aspect, for example for the status stative , $_{\text {, }}$ transforming individual states of affairs into habitual ones, which do not require referential undergoers. Thus an individual pf. event napisal roman 'wrote a novel' turns into a secondary (habitual) ipf. state pisal (roman) in the sense of 'used to write a novel' or less specifically 'used to write novels' or even 'used to write' (was a writer). Thus, in terms of status aspect even pisat' with a non-canonical undergoer argument remains in a grammatical relation with pf. napisat'.

In contrast, pisat' and čitat' in their secondary atelic reading share aspectual behavior with primary activities like rabotat' 'to work', in allowing for the limitative to transform their temporal boundary B2 into a temporally fixed one, which corresponds to limitative ${ }_{3}$ status. It is in terms of this type of aspectual modification that the delimitative verbs porabotat', počitat', popisat', with the interaction meaning 'to work/write/read for a limited period of time', result as pf. partners of atelic imperfectives.

Note that the non-canonical filling of the undergoer argument of the lexemes in question is just the way in which processive ${ }_{2}$ status aspect works. It transforms the fixed boundary provided by its valency structure into a temporal one. This means that this procedure may be seen in terms of aspect, that is grammar. All in all, it does not seem necessary to separate GTER lexemes like 'to write' into two lexemes, a telic obligatorily transitive aspectual pair pisat'/napisat' and an atelic only optionally transitive one pisat'/popisat'. They should rather be seen as a ternary GTER complex pisat'/napisat'/popisat', expressing all aspectual focus and status operations with the help of the respective forms of all three partner verbs that belong to the full paradigm of this lexeme. This is a logical consequence of strictly applying the focusing and status-modifying rules of the ILA model.

Let us come back to the semelfactive subgroup of TTER 3 lexemes of the type stuknut'/stučat' 'to knock', whose basic actional meaning is that of a punctual state 


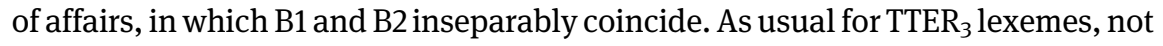
having neither a $\mathrm{RSTA}_{1}$ nor an $\mathrm{ACTI}_{2}$ component, both focus operations of the ipf. aspect are excluded, whereas the limitative ${ }_{3}$ function of the pf. aspect is reduced to an empty application, as the lexical DTD is already 3 like that of the aspect function. Prototypically the TTER 3 meaning is expressed by the pf. verb alone, here stuknut'. Nevertheless an activity reading is possible, expressed by the ipf. partner verb stučat', which, as a matter of fact, does not have any TTER $_{3}$ properties, but behaves like an atelic verb of the $\mathrm{ACTI}_{2}$ class. This behavior is, of course due to the status processive ${ }_{2}$ transforming the telic punctual meaning into an atelic activity, consisting of an ongoing iteration of 'knocks'. Just like the secondary $\mathrm{ACTI}_{2}$ reading of pisat' 'to write', the secondary $\mathrm{ACTI}_{2}$ reading of stučat' may undergo a limitative ${ }_{3}$ status operation, expressed by the delimitative verb postučat' 'to knock for a limited period of time'. So, instead of an aspectual pair we get once again a ternary complex of verbs expressing all aspectual operations, the TTER 3 lexeme stuknut'/ stučat'/postučat'. Just like the optionally transitive pisat', the ipf. aspect of stučat' may also express stative ${ }_{1}$ status, resulting in a habitual meaning, i.e. a secondary RSTA $_{1}$ state. $^{26}$

$\mathrm{TTER}_{3}$ lexemes outside the semelfactive subgroup, like naxodit'/najti IPFV/PFV 'to find', prixodit'/prijti' 'to come', do not allow for continuous iteration, which excludes the processive status ${ }_{2}$ operation in addition to processive ${ }_{2}$ focus. This is why the ipf. verbs naxodit' and prixodit' do not express neither telic nor atelic processes, in contrast to habitual states of affairs going back to the statusmodifying stative operation. ${ }^{27}$

To sum up, inappropriate filling of the valencies of GTER lexemes and actual iteration of TTER semelfactives are simply two lexeme-specific results of status-

26 Ternary complexes like those claimed in this section have been proposed by other authors, too, e.g. Tatevosov (2002: 371), though not necessarily under the claim of absolute lexical identity or as the result of applying a set of interaction rules. By means of the integration of aktionsarten, being able to represent a given basic lexical meaning in certain contexts, for example the "ingressive" one of the type zastučat' PFv 'to start knocking', even still larger complexes are possible, which, however, cannot be claimed as lexically fully identical. In Breu (1985) in this respect a difference is made between purely grammatical aspectual pairs and "peripheral" context-driven pairs. In the ILA model it is crucial that all aspectually marked (IPFv or PFv) verbs united in a lexeme must have exactly the same lexical meaning, whereas all additional surface meanings have to be derived by means of their interaction with focus or status aspect. Only under this precondition it makes sense to understand delimitative and semelfactive perfectives as partner verbs of atelic imperfectives, i.e. as forms of the same lexeme.

27 The situation changes if the agent valency of prixodit' is filled with an unlimited quantity of referents, which allows for distributive iteration, for example, prixodili gosti 'guests were coming in (the whole day long, one after the other)'. This is a secondary atelic activity, due to the statusmodifying processive, similar to the continuous iteration of the semelfactives. 
aspect operations. Actually, the parallelism between the two groups goes still further. If we decompose a semelfactive meaning in terms of the realization of an undergoer, i.e. to something like to $k n o c k \Rightarrow$ to execute a knock, the atelic reading of stučat' would again be the result of an inappropriate filling of the undergoer valency with an unspecific argument (unlimited quantity by iteration).

\section{Summary and conclusion}

This chapter has dealt with the extended version of the model of the interaction of lexical (actional) meaning and (grammatical) aspect (ILA) and its further development. In particular, two further features were added to this component-based model. The first one was "status aspect" (=the status-modifying type of aspect), different from "focus aspect", operating on the components of the actional verbal meaning. The other one was the integration of the effects of non-canonical arguments filling the valencies of verb lexemes into the model.

It has to be emphasized that the ILA model is conceptualized as "universal", i.e. the established interaction classes are independent of the morphosyntactic characteristics of individual languages. This is important, as most examples come from Russian, where the full paradigm of a verb lexeme regularly consists of the grammatical forms of two verbs (aspectual pairs) with the same lexical meaning but differing in the aspect grammeme they express. Although in Slavic the formal means of expression of aspect in such pairs are based on the derivational procedures of prefixation, suffixation and suppletion, their only function is the grammatical differentiation of the aspect grammemes "perfective" versus "imperfective". This "grammatical derivation" is functionally equivalent to aspectual inflection, periphrases and the like. Thus, what has been said about the interaction of lexicon and grammar in Slavic is equally valid for languages with inflectional aspect, too.

Not only the morphosyntactic means of expression of verbal aspect are different in the individual languages, but also the distribution of the single aspect functions (grams) like processive or stative with respect to the language-specific grammemes. In Slavic, processive and stative are functions of the imperfective grammeme. The same is true for the Romance or Albanian imperfect. In contrast, the processive is a function of the English progressive, whereas the stative is a function of the simple form. The aspect-sensitive characteristics of largely equivalent lexical meanings of different languages may also be to a certain extent language-specific. As a consequence, they can fall into different classes of the universal ILA system, serving as a typological yardstick for actional characteristics based on temporal dynamics. Thus, for example, the Russian lexeme prixodit'/ 
prijti IPFV/PFV was described as belonging to the TTER class, incompatible with the processive (DTD 2), unlike its English equivalent to come. Another example was the ISTA character of Italian avere, contrasting with its English and Russian equivalents to have, imet', which as RSTA lexemes cannot express the beginning of the state by means of verbal aspect. Finally, in the individual languages, polysemy (and homonymy) may imply a different actional classification of their partial meanings, with different aspectual behavior (hybrid classification) for each of them, including different aspectual morphology (= different correlative partners).

The ILA model is based on the class-forming degrees of temporal dynamics (DTD) of both lexical (actional) meanings and aspectual functions. In both cases four basic DTD classes have been established, from DTD 0 to DTD 3, thus ranging from "no change of situation expected in the course of time" to "obligatory change" with two intermediate classes of "possible change of situation" and "temporary situation, obligatorily finishing in some point of time”. In the lexicon, in addition to such simple classes, "complex" classes exist, having single class features as their components. For example the gradually terminative GTER class is composed of a temporary activity (ACTI, DTD 2) and a telic component (TTER, DTD 3) and the inceptively static ISTA class consists of a telic (TTER, DTD 3) and a state component (RSTA 1).

As for the interaction of lexical semantics and grammatical aspect, actional classes are incompatible with the aspect functions showing different DTD characteristics, while the aspect functions with the same DTD as the lexical meaning in question are applied emptily. For example, the English state verb to belong (DTD 1) is incompatible with the progressive (processive function, DTD 2), whereas the simple form with its stative function (DTD 1) is applied emptily (it only confirms the actional characteristics of a state that can possibly change in the future). On the other hand, the limitative function (DTD 3) of the simple form is likewise incompatible with to belong. The same is true for its Russian equivalent prinadležat'. But, as in Russian the limitative is the only function expressed by the perfective aspect, it is this grammeme as a whole that is incompatible with this verb (thus there is no pf. form at all).

In the complex actional classes, the interaction with aspect functions is a direct consequence of the interaction characteristics of the simple classes: The aspect function in question focuses the actional component with the same DTD. Thus an English GTER verb like to convince (DTD 2, 3) gets a processual interaction meaning with the progressive (DTD 2), and the interaction meaning of a total event (and its result) with the simple form in its limitative function (DTD 3). The same is true for the corresponding Russian lexeme ubeždat'/ubedit' IPFV/PFv, in which the processive function is expressed by the ipf. verb and the limitative function by its 
pf. correlate. Note that the two aspectually differentiated verbs form only one (aspectually complete) lexeme, just like the single verb to convince in English.

Similarly, an English ISTA verb (DTD 1,3) like to understand may have the focus on its TTER (DTD 3) component with the interaction meaning of the beginning of the state, expressed by the limitative function of the simple form. On the other hand, it can have the focus on its RSTA component (DTD 1), too, realized by means of the stative function of the simple form. In contrast, this verb is incompatible with the progressive, which has the processive (DTD 2) as its only aspectual function. Its Russian equivalent, the aspectual pair ponjat'/ponimat' PFv/ IPFV, is compatible with both aspects, as the pf. aspect grammeme, by means of its limitative function (DTD 3), focuses the TTER (DTD 3) component, with the interaction meaning of "understanding/grasping" as a total event, being at the same time the beginning of the state (of having understood). In contrast, the ipf. correlate focuses the state component (DTD 1) directly, by means of the stative function it expresses. The processual function (DTD 2) of the ipf. aspect is, of course, incompatible with all ISTA lexemes in all languages.

Focusing (stressing) a component is not the same thing as selecting it by suppressing the other component(s). For example, focusing the activity component of a telic GTER lexeme does not lead to synonymy with an activity lexeme of the simple ACTI class. In the first case, the ACTI component, focused by the processive function, may be contrasted with the TTER component, focused by the limitative function, in a sentence like on ubeždal menja, da ne ubedil 'he was convincing me (=was trying to convince me), but did not convince me', thus stating that the inherent final boundary of the state of affairs has not been reached. In simple ACTI verbs such an opposition is not possible, because a state of affairs like rabotat' 'to work' is realized in every single moment of its existence. In Russian, such verbs find their pf. partner in perfectives with a delimitative interaction meaning, like porabotat', referring to the fluid temporary boundary of the ACTI class (no inherent final boundary). Russian aspect morphology is sensitive for this difference in having different pf. partners, for example, pisat'/popisat' 'to write' (ACTI), but pisat'/napisat' 'to write (sth.)' (GTER).

Likewise ISTA lexemes like ponjat'/ponimat' may not simply be separated into an event, expressed by the pf. verb, and a state, expressed by the ipf. verb. Both of them have the same lexical meaning, but - as has been demonstrated before - the interaction meaning of the pf. verb is "an event, which is the beginning of the state of understanding" and that of the ipf. verb is "the state following the event of understanding/grasping”. A simplistic view of the ipf. verb as expressing just a state and nothing else is not adequate. This follows, among other things, also from the usage of ponimat' IPFV in the case of habitual events (of understanding/ grasping). 
It was shown that the modification of the actional status of a lexical meaning is a second way of manipulating lexical DTD characteristics by means of aspect functions. But unlike the component-focusing type it really changes the DTD characteristics of lexemes. Thus, by means of the stative (DTD 1) function of the ipf. aspect all lexemes with a higher DTD become secondary states (DTD 1), with the interaction meaning of habituality, like in the just-mentioned case of Russian ponimat' IPFV replacing episodic ponjat' PFV. The same would be true for habitual ubeždat' 'to convince' IPFv, replacing in this case ubedit'. As in English the stative and the limitative function are both expressed by the simple form, there is no such aspectual interplay; instead stative status may be expressed by special periphrases, for example, with the auxiliary would + INF. In this language there is, however, a formal differentiation between states of affairs presented as ongoing processes (processive focus, DTD 2) by means of the progressive periphrasis and their presentation as habitual (stative status, DTD 1), expressed by means of the simple form: $s$ /he is convincing me versus she (always) convinces me.

The processive may be applied to verbal states of affairs as a status-modifying aspect, too. In this case telic verbs (with a DTD 3 component) become atelic processes (actual aterminativization). This is, however, only possible under certain conditions. An example is continuative iteration in the case of semelfactives like stuknut' 'to knock', whose ipf. partner stučat' may expresses a process consisting of an open quantity of single events (processive status). The same is true for English is knocking'. While stučat' IPFV is also the habitual counterpart of stuknut' PFv (stative status), in English the aspectually ambiguous simple form expresses the episodic and the habitual event alike.

In most aspect languages status-modifying aspect seems just an additional possibility. In Colloquial Upper Sorbian, however, only status aspect exists, without any kind of focus aspect. So traditional pf. forms express only telic and pf. forms only atelic states of affairs. So, in this Slavic minority language the actional feature of telicity has been grammaticalized on the basis of the traditional Slavic aspect system.

As was shown in the last section of this chapter, both aspect types interact with the argument structures of verb lexemes. In order to handle the dependence of class assignment upon the arguments actually filling the lexically given valencies, we might set up two essential premises, allowing for a basic affiliation and the possibility of change by means of the arguments used:

1. Every verbal lexeme has a prototypical valency structure and a basic DTD-class affiliation

2. Divergent (non-canonical) arguments may lead to a change of the class assignment of the basic meaning 
This means that we have to keep in mind that the real aspectual behavior of a given lexeme may always differ from its prototypical actional properties. It is an important task to find systematic rules for these deviations, which may lead to a dynamic classification, in which valencies and their arguments will play an important role. These rules could then be formalized in analogy to the focusing and modifying formulas for the interaction meanings, presented in Sections 2.4 and 3.

\section{Abbreviations}

$\begin{array}{ll}\text { 3 } & \text { 3rd person } \\ \text { ACC } & \text { accusative } \\ \text { ACTI } & \text { activity } \\ \text { AOR } & \text { aorist } \\ \text { AUX } & \text { auxiliary } \\ \text { B1 } & \text { initial boundary } \\ \text { B2 } & \text { final boundary } \\ \text { DAT } & \text { dative } \\ \text { DTD } & \text { degree of temporal dynamics } \\ \text { GEN } & \text { genitive } \\ \text { GTER } & \text { gradually terminative } \\ \text { ILA } & \text { interaction of the lexicon with aspect } \\ \text { INCO } & \text { incorporative } \\ \text { INDF } & \text { indefinite article } \\ \text { INF } & \text { infinitive } \\ \text { INS } & \text { instrumental } \\ \text { Ipf. } & \text { imperfective } \\ \text { IPFV } & \text { imperfective } \\ \text { IPRF } & \text { imperfect } \\ \text { ISTA } & \text { inceptively static } \\ \text { LOC } & \text { locative } \\ \text { M } & \text { masculine } \\ \text { N } & \text { neuter } \\ \text { NEG } & \text { negation } \\ \text { pf. } & \text { perfective } \\ \text { PFV } & \text { perfective } \\ \text { PL } & \text { plural } \\ \text { PRF } & \text { perfect } \\ \text { PROG } & \text { progressive } \\ \text { PRS } & \text { present tense } \\ \text { PST } & \text { past tense } \\ \text { PTCP } & \text { participle } \\ \text { REFL } & \text { reflexive } \\ & \end{array}$




$\begin{array}{ll}\text { RSTA } & \text { relatively static } \\ \text { SF } & \text { simple form } \\ \text { SG } & \text { singular } \\ \text { TSTA } & \text { totally static } \\ \text { TTER } & \text { totally terminative }\end{array}$

\section{References}

Anstatt, Tanja. 1996. Interaktion von aktionalen Verbfunktionen und semantischen Kasus der Aktanten am Beispiel russischer Transitiva. In Franz Schindler (ed.), Linguistische Beiträge zur Slavistik aus Deutschland und Österreich IV, 7-28. Sagner: München.

Bondarko, Aleksandr V. 1995. Semantika glagol'nogo vida $v$ russkom jazyke [The semantics of verbal aspect in the Russian language]. Frankfurt a.M.: Peter Lang.

Boneh, Nora \& tukasz Jędrzejowski. 2019. Reflections on habituality across other grammatical categories. STUF/Language Typology and Universals 72(1). 1-20.

Breu, Walter. 1984a. Grammatische Aspektkategorie und verbale Einheit. In Wolfgang Girke \& Helmut Jachnow (eds.), Aspekte der Slavistik, 7-25. Sagner: München.

Breu, Walter. 1984b. Zur Rolle der Lexik in der Aspektologie. Die Welt der Slaven 29. N.F. 8. 123-148.

Breu, Walter. 1985. Handlungsgrenzen als Grundlage der Verbklassifikation. In Werner Lehfeldt (ed.), Slavistische Linguistik 1984, 9-34. Sagner: München.

Breu, Walter. 1994. Interactions between lexical, temporal, and aspectual meanings. Studies in Language 18(1). 23-44.

Breu, Walter. 1998. Komplexe aktionale Verbklassen, insbesondere Inchoativa. In Tilman Berger \& Jochen Raecke (eds.), Slavistische Linguistik 1997, 55-80. Sagner: München.

Breu, Walter. 2005. Verbalaspekt und Sprachkontakt. Ein Vergleich der Systeme zweier slavischer Minderheitensprachen (SWR/MSL). In Sebastian Kempgen (ed.), Slavistische Linguistik 2003, 37-95. Sagner: München.

Breu, Walter. 2009. Verbale Kategorien: Aspekt und Aktionsart. In Sebastian Kempgen, Peter Kosta, Tilman Berger \& Karl Gutschmidt (eds.), Die slavischen Sprachen - The Slavic languages, vol. 1, 209-225. Berlin \& New York: De Gruyter.

Breu, Walter. 2012. Aspect forms and functions in Sorbian varieties. STUF/Language Typology and Universals 65(3). 246-266.

Breu, Walter. 2014. Funkcii nastojaščego i imperfekta soveršennogo vida i imperfekta nesoveršennogo vida $v$ molizsko-slavjanskom mikrojazyke [The functions of the perfective present and imperfect and of the perfective imperfect in the Molise Slavic minority language]. Scando-Slavica 60(2). 321-350.

Breu, Walter, Jasmin Berghaus \& Lenka Scholze. 2016. Der Verbalaspekt im totalen Sprachkontakt. Moliseslavisch, Obersorbisch und Burgenlandkroatisch im Vergleich. In Walter Breu \& Tilmann Reuther (eds.), Slavistische Linguistik 2014. Wiener Slawistischer Almanach 77/2, 55-116. Frankfurt a.M.: Peter Lang.

Čertkova, M. Ju. 1996. Grammatičeskaja kategorija vida v sovremennom russkom jazyke [The grammatical category of aspect in modern Russian]. Moskva: Izdatel'stvo Moskovskogo universiteta.

Comrie, Bernard. 1976. Aspect. Cambridge: Cambridge University Press. 
Dahl, Östen. 1981. On the definition of telic-atelic (bounded-nonbounded) distinction. In Philip Tedeschi \& Annie Zaenen (eds.), Syntax and semantics, vol. 14: Tense and aspect, 79-90 New York: Academic Press.

Gardenghi, Monica. 1998. L'interazione fra lessico e aspetto nel sistema del verbo italiano. Bayreuth: University of Bayreuth Dissertation.

Garey, Howard B. 1957. Verbal aspect in French. Language 33. 91-110.

Glovinskaja, M. Ja. 1982. Semantičeskie tipy vidovyx protivopostavlenij russkogo glagola [Semantic types of aspectual oppositions of the Russian verb]. Moskva: Nauka.

Isačenko, Alexander V. 1968. Die russische Sprache der Gegenwart. Teil I. Formenlehre. München: Hueber.

Johanson, Lars. 1971. Aspekt im Türkischen. Vorstudien zu einer Beschreibung des türkeitürkischen Aspektsystems. Uppsala: Acta Universitatis Upsaliensis.

Karolak, Stanisław. 2003. Zametki o teorii interakcii leksičeskogo značenija i vida (ILA) Val'tera Broja [Remarks on the theory of the interaction of lexical meaning and aspect (ILA) of Walter Breu]. Russian Linguistics 38. 137-162.

König, Christa. 1993. Aspekt im Maa. Köln: Institut für Afrikanistik, Universität zu Köln.

Koschmieder, Erwin. 1973. Tak zwane czasowniki 'preterytywne' *posěděti, *poležati [The socalled 'preteritive' verbs *posěděti, *poležati]. In Johannes Holthusen, Erwin Koschmieder, Reinhold Olesch \& Erwin Wedel (eds.), Slavistische Sudien zum VII. Internationalen Slavistenkongreß in Warschau 1973, 298-304. München: Rudolf Trofenik.

Krifka, Manfred. 1998. The origins of telicity. In Susan Rothstein (ed.), Events and grammar, 197-235. Dordrecht: Kluwer.

Lehmann, Volkmar. 2009. Aspekt und Tempus im Slavischen. In Sebastian Kempgen, Peter Kosta, Tilman Berger \& Karl Gutschmidt (eds.), Die slavischen Sprachen - The Slavic languages, vol. I, 526-556. Berlin \& New York: De Gruyter.

Leluda-Voß, Christina. 1997. Die Perfekterfassung und das neugriechische Perfekt. Frankfurt a.M.: Peter Lang.

Li, Chor-Shing. 1991. Beiträge zur kontrastiven Aspektologie. Das Aspektsystem im Modernen Chinesisch. Frankfurt a.M.: Peter Lang.

Maslov, Jurij S. 1948. Vid i leksičeskoe značenie glagola v sovremennom russkom literaturnom jazyke [Aspect and lexical meaning of the verb in the modern Russian literary language]. Izvestija Akademii Nauk, otdelenie literatury i jazyka 7(4). 303-316.

Mehlig, Hans Robert. 2006. Inkrementelles Patiens und Verbalaspekt im Russischen: Zum Aspektgebrauch in Prädikationen mit Komplementen, die durch Numerale und Maßangaben begrenzt sind. In Tilman Berger, Jochen Raecke \& Tilmann Reuther (eds.), Slavistische Linguistik 2004/2005, 301-333. Sagner: München.

Padučeva, Elena V. 2004. Dinamičeskie modeli v semantike leksiki [Dynamic models in lexical semantics]. Moskva: Jazyki slavjanskoj kul'tury.

Padučeva, Elena. 2015. Momental'nye glagoly soveršennogo vida i ix proizvodnye imperfektivy [Momentary verbs of perfective aspect and their derived imperfectives]. In Motoki Nomachi, Andrii Danylenko \& Predrag Piper (eds.), Grammaticalization and lexicalization in the Slavic languages, 333-346. Sagner: München.

Persohn, Bastian. 2021. Two-phase verbs: A crosslinguistic look at an actional class, vol. 74(3-4). 427-434.

Sasse, Hans-Jürgen. 1991a. Aspekttheorie. In Hans-Jürgen Sasse (ed.), Aspektsysteme. Arbeitspapiere, vol. 14, 1-35. Köln: Institut für Sprachwissenschaft. 
Sasse, Hans-Jürgen. 1991b. Arvanitika. Die albanischen Sprachreste in Griechenland. Teil I. Wiesbaden: Harrassowitz.

Sasse, Hans-Jürgen. 2002. Recent activity in the theory of aspect: Accomplishments, achievements, or just non-progressive state? Linguistic Typology 6(2). 199-271.

Schnell, Stefan. 2011. A grammar of Vera'a, an Oceanic language of North Vanuatu. Available at: https://www.academia.edu/2317752/Schnell_2011_A_grammar_of_Vera a_an_Oceanic_ language_of_North_Vanuatu.

Scholze, Lenka. 2008. Das grammatische System der obersorbischen Umgangssprache im Sprachkontakt. Bautzen: Domowina.

Tatevosov, Sergey G. 2002. The parameter of actionality. Linguistic Typology 6(3). 317-401.

Tatevosov, Sergey G. 2016. Glagol'nye klassy i tipologija akcional'nosti [Verb classes and the typology of actionality]. Moskva: Jazyki slavjanskoj kul'tury.

Vendler, Zeno. 1957. Verbs and times. The Philosophical Review 66. 143-160.

Wiemer, Björn (B'ërn Vimer). 2019. Tipologija akcional'nosti: svojstva finitnoj klauzy, klassifikacija glagolov i edinyj podxod k slovoizmenitel'nomu i derivacionnomu vidu [Typology of actionality: Properties of the finite clause, classification of verbs and a uniform approach to inflectional and derivational aspect]. Voprosy Jazykoznanija 2019(1). 93-129.

Zaliznjak, Anna A., Irina L. Michaèljan \& Aleksej D. Šmelev. 2015. Russkaja aspektologija: vzaščitu vidovoj pary [Russian aspectology: In defence of the aspectual pair]. Moskva: Jazyki slavjanskoj kul'tury. 